\title{
PENGARUH KARAKTERISTIK PERUSAHAAN TERHADAP PENGUNGKAPAN \\ CORPORATE SOCIAL RESPONSIBILITY (CSR)
}

\author{
Lu'lu’il Maknuun, SE., MM.
}

E-mail - luluilmaknuun92@gmail.com

\begin{abstract}
This study was tested the influence of the firm characteristics to the Corporate social responsibility disclosure (CSRD) of insurance companies in Indonesia. The purpose of this research is to analyze the effect of company characteristics such as profitability, firm size, leverage and board of commisioners size on the corporate social responsibilitydisclosure on all insurance companies listed on the Indonesia Stock Exchange in 2009 until 2012.

This research is an empirical study with purposive sampling techniques in data collection with the following criteria: 1. Insurance companies listed on the Indonesia Stock Exchange in 2009 until 2012. 2. Completed annual reports published in 2009 until 2012. The data obtained from annual report of Insurance companies listed on the Indonesia Stock Exchange. Data were analyzed bymultiple linear regressions to examine the influence of firm characteristics on the CSRD made by the firm.

The hypothesis in this research is as follows, 1. Profitability of insurance company affect positively on the CSRD of the company, 2. Leverage of the insurance company affect negatively on the CSRD of the company, 3. Firm size affect positively on the CSRD of the company, 4. Board of commisioners size affect positively on the level of risk disclosure. The results from the test of hypothesis indicated that the firm's size and company's board of commisioners' size are significantly influenced on the CSR disclosure. Furthermore, leverage and profitabilityor the company does not significantly influence the level of CSR disclosure. The result of this study provides information for investor about the level of corporate social responsibility disclosure that company could have, and also useful to give information for decision making.
\end{abstract}

\section{PENDAHULUAN}

Dampak kepedulian masyarakat terhadap aktivitas suatu perusahaan keuangan yang berkontribusi pada perkembangan ekonomi di masyarakat meningkat seiring dengan meningkatnya kesadaran publik mengenai pentingnya peran perusahaan tersebut Hal ini menyebabkan beberapa perusahaan yang lebih berorientasi pada tingginya laba lebih menunjukan performa kinerjanya kepada para investor. Oleh karena itu, pemangku kepentingan tidak hanya menuntut perusahaan penghasil limbah saja untuk melaporkan pertanggungjawaban sosialnya atau yang disebut Corporate Social Responsibility, tetapi juga perusahan keuangan. Corporate Social Responbility (CSR) adalah komitmen perseroan untuk berperan serta dalam pembangunan ekonomi berkelanjutan guna meningkatkan kualitas kehidupan dan lingkungan yang bermanfaat, bagi perseroan sendiri, komunitas setempat, serta masyarakat pada umumnya (Pasal 1 butir 3 UU No.40/2007 tentang PT).

Selama ini akuntansi dianggap sebagai salah satu penyebab kerusakan lingkungan karena akuntansi memiliki peranan penting sebagai alat pertanggungjawaban dan alat pengendali terhadap aktivitas setiap unit usaha justru hanya berpihak pada stockholders (mainstream accounting atau conventional accounting). Dengan meningkatnya kesadaran masyarakat akan kelestarian alam untuk kelangsungan hidup manusia dan penekanan pada kesejahteraan sosial, kini telah mengubah konsep akuntansi untuk lebih memerhatikan kepedulian terhadap sosial dan lingkungan. (Andreas dan Lawyer, 2011)

Pengguna laporan keuangan menggunakan pelaporan CSR yang relevan untuk membantu menjustifikasi atau mengoreksi ekspektasi masa lalu, yakni memiliki nilai umpan balik. Menurut Pambudi (2006), terdapat berbagai variasi cara pandang perusahaan terhadap CSR, apakah hal ini dianggap sebagai hal yang penting atau tidak. Cara pandang ini selanjutnya akan memengaruhi praktik CSR yang dilakukan oleh perusahaan dan juga akan berdampak pada pengungkapan CSR yang disusunnya. Pelaporan CSR dilakukan oleh berbagai perusahaan yang melakukan kegiatan CSR sebagai bukti serta informasi bila perusahaan tersebut benar-benar melakukan sesuatu yang menunjukkan kepedulian dan ikut berperan serta dalam kegiatan yang bertujuan meningkatkan dampak positif pada komunitas sosial. 
Menurut Mulyanita (2009) dalam Purwitasari (2011), alasan perusahaan keuangan mengungkapkan pelaporan sosial adalah karena adanya perubahan paradigma pertanggung jawaban, dari manajemen ke pemilik saham menjadi manajemen kepada seluruh stakeholder. Hal ini ditegaskan oleh Ikatan Akuntan Indonesia (IAI) dalam Pernyataan Standar Akuntansi Keuangan (PSAK) No. 1 (revisi 1998) di paragraf sembilan yang secara implisit menyarankan agar melakukan pengungkapan tanggung jawab terhadap masalah lingkungan dan sosial. perusahaan di bidang keuangan di Indonesia melakukan pelaporan sosial untuk menjaga citra perusahaan di masyarakat.

Dalam UU Nomor 40 Tahun 2007 tentang Perseroan Terbatas pada bab IV bagian kedua pasal 66 (2) poin c menyebutkan bahwa dalam laporan tahunan perusahaan harus memuat laporan pelaksanaan tanggung jawab sosial dan lingkungan, berarti laporan tanggung jawab sosial merupakan laporan yang wajib dilaporkan pada laporan tahunan perusahaan yang dipublikasikan untuk shareholder dan stakeholder oleh perusahaan. Menurut Hackston dan Milne (1996) walaupun fenomena pengungkapan tanggung jawab sosial ini telah muncul lebih dari dua dekade, namun penelitian tentang praktik pengungkapan tanggung jawab sosial sepertinya terpusat di Amerika Serikat, Inggris dan Australia. Hanya sedikit penelitian yang dilakukan di negara lain seperti Kanada, Jerman, Jepang, Selandia Baru, Malaysia dan Singapura.

Adapun dampak sosial yang ditimbulkan oleh masing-masing perusahaan tentunya tidak selalu sama, karena terdapat banyak faktor yang membedakan satu perusahaan dengan perusahaan lainnya meskipun mereka berada dalam satu jenis usaha yang sama. Faktor-faktor yang membedakan perusahaan disebut karakteristik perusahaan, yang di antaranya adalah size (ukuran perusahaan), tingkat likuiditas, tingkat profitabilitas, tingkat leverage, kendala sosial yang dimiliki, umur perusahaan, profil perusahaan, struktur dewan komisaris, negara pemilik suatu perusahaan, negara tempat didirikannya perusahaan, dll. Semakin kuat karakteristik yang dimiliki suatu perusahaan tersebut dalam menghasilkan damp ak sosial bagi publik tentunya akan semakin kuat pula pemenuhan tanggung jawab sosialnya kepada publik. (Veronica, 2009)

Penelitian mengenai hubungan karakteristik perusahaan dengan CSR disclosure telah banyak dilakukan dan memiliki hasil yang beragam. Di antara penelitian tersebut dilakukan oleh Karina (2013), Wardani (2013), Anggraini (2006), dan Septiani (2013). Beberapa studi telah mencoba membahas konten pelaporan tanggung jawab sosial.Melihat penelitian yang menggunakan data perusahaan asuransi masih belum ditemui.Peneliti sebelumnya dilakukan oleh Wardhani (2013) mengungkapkan bahwa karakteristik perusahaan merupakan faktor-faktor yang mempengaruhi pengungkapan pelaporan tanggung jawab sosial.

\section{Rumusan Masalah}

Karakteristik perusahaan memiliki hubungan yang logis dengan pengungkapan CSR nya. Semakin tumbuhnya kesadaran dari stakeholder terhadap isu-isu pengungkapan CSR oleh perusahaan, secara tidak langsung juga berdampak pada item-item yang diungkapan oleh perusahaan yang dijadikan obyek penelitian ini. Hal ini karena perusahaan asuransi bergerak langsung kepada masyarkat luas sehingga penelitian ini merasa perlu dilakukan. Dan juga perusahaan asuransi independen yang semakin banyak bermunculan dirasa menguatkan peneliti untuk melakukan penelitian ini. Disamping itu Corporate social responsibility disclosure dapat dipengaruhi oleh hipotesis yaitu : rencana bonus dari perusahaan, hutang perusahaan dan pembiayaan politik dari perusahaan. Yang dapat digambarkan oleh profitabilitas perusahaan, tingkat leverage, ukuran perusahaan dan dewan komisarisnya.Variabel yang digunakan memiliki nilai yang cukup besar dalam laporan posisi keuangan dan laporan tahunan perusahaan pengembangan sehingga dari penelitian ini masih perlu diperhatikan. Oleh karena itu dapat dirumuskan masalah penelitian sebagai berikut: (i) apakah Profitabilitas dari perusahaan asuransi di Indonesia berpengaruh terhadap pengungkapan pelaporan tanggung jawab sosial perusahaan asuransi di Indonesia?, (ii) apakah tingkat hutang perusahaan asuransi di Indonesia berpengaruh terhadap pengungkapan pelaporan tanggung jawab sosial perusahaan asuransi di Indonesia?, (iii) apakah ukuran perusahaan dari perusahaan asuransi di Indonesia berpengaruh terhadap pengungkapan pelaporan tanggung jawab sosial perusahaan asuransi di Indonesia?, (iv) apakah ukuran dewan komisaris perusahaan asuransi di Indonesia berpegaruh terhadap pengungkapan pelaporan tanggung jawab sosial perusahaan asuransi di Indonesia? 


\section{KERANGKA PEMIKIRAN TEORITIS DAN PERUMUSAN HIPOTESIS}

\section{Landasan Teori \\ Teori Signaling}

Signalling Theory (Teori Sinyal), teori ini memberikan suatu sinyal dimana dari pihak pengirim atau pemilik informasi berusaha memberikan suatu informasi relevan yang dapat dimanfaatkan oleh pihak penerima informasi. Kemudian pihak penerima akan menyesuaikan pengambilan keputusannya sesuai dengan pemahamannya terhadap sinyal tersebut. Kegiatan-kegiatan yang dilakukan perusahaan secara tidak langsung pasti juga berdampak pada stakeholders seperti karyawan, investor, pemasok, pemerintah, konsumen, serta masyarakat sehingga kegiatan-kegiatan tersebut menjadi perhatian dan minat dari para stakeholders, terutama para investor dan calon investor sebagai pemilik dan penanam modal. Maka dari itu dirasa perlu oleh perusahaan untuk memberi suatu informasi yang lengkap bagi para calon stakeholder tersebut. Sehingga perusahaan melaporkan lebih dari sekedar laporan keuangan, dengan mengungkapkan laporan tambahan yaitu pelaporan tahunan tentang aktifitas CSR perusahaan.

Signaling theory menekankan bahwa perusahaan pelapor dapat meningkatkan nilai perusahaan melalui pelaporannya. Jika perusahaan gagal dalam menyajikan informasi yang lebih, maka para stakeholders hanya akan menilai perusahaan sebagai perusahaan rata-rata sama dengan perusahaanperusahaan yang tidak mengungkapkan laporan tambahan (Drever et al., 2007 dalam Indrawan, 2011). Hal tersebut dapat meningkatkan motivasi bagi perusahaan-perusahaan untuk menunjukan sesuatu melalui laporan keuangan, bahwa mereka lebih baik daripada perusahaan lain yang tidak melakukan pengungkapan. Dengan demikian, signaling theory menjelaskan bahwa perusahaan akan cenderung memberikan informasi yang lebih lengkap untuk membangun reputasi yang akan terlihat lebih baik dibandingkan perusahaan-perusahaan yang tidak melakukan pengungkapkan, yang pada akhirnya akan menarik para investor.

\section{Teori Agensi}

Teori Agensi atau teori keagenan dalam Hendriksen (2000), dalam Laksmitaningrum (2013) menjelaskan hubungan antara agen (manajemen suatu usaha) dan prinsipal (pemilik usaha). Hubungan keagenan (agency relationship) muncul ketika principal membayar manajer profesional untuk bertindak atas namanya dan mendelegasikan kekuasaan untuk membuat keputusan yang berhubungan dengan perusahaan atau karyawan. Menurut teori ini, agent secara alami memiliki kepentingan sendiri (conflict of interest). Oleh karena itu, pemilik harus mengawasi agent dan membuat kompensasi dan evaluasi kinerja yang dapat menyelaraskan tujuan pemilik dengan tujuan agent. Kinantika (2013) menambahkan, penelitian tentang teori agensi yang dilakukan oleh Davidson dan Jiraporn (2004) menggunakan pandangan tradisional sebagai titik awal penelitiannya bahwa pemisahan kepemilikan dan pengendalian di perusahaan modern harus dilakukan, hal ini bersamaan dengan timbulnya asimetri atas informasi dalam perusahaan bisa menimbulkan posibilitas bagi agent (manajer) untuk melakukan tindakan oportunis yang berbanding terbalik dengan objektif dari principal (pemilik), dan akan timbul kecenderungan untuk memenuhi kepentingan pribadi yang merupakanmasalah agensi. Jika hal ini terjadi maka pemegang saham dapat membuat keputusan yang tidak optimal. Untuk menutupi masalah agensi yang terjadi dalam perusahaan manajer menggunakan laporan CSR. Berdasarkan uraian diatas dapat digambarkan kerangka pemikiran sebagai berikut.

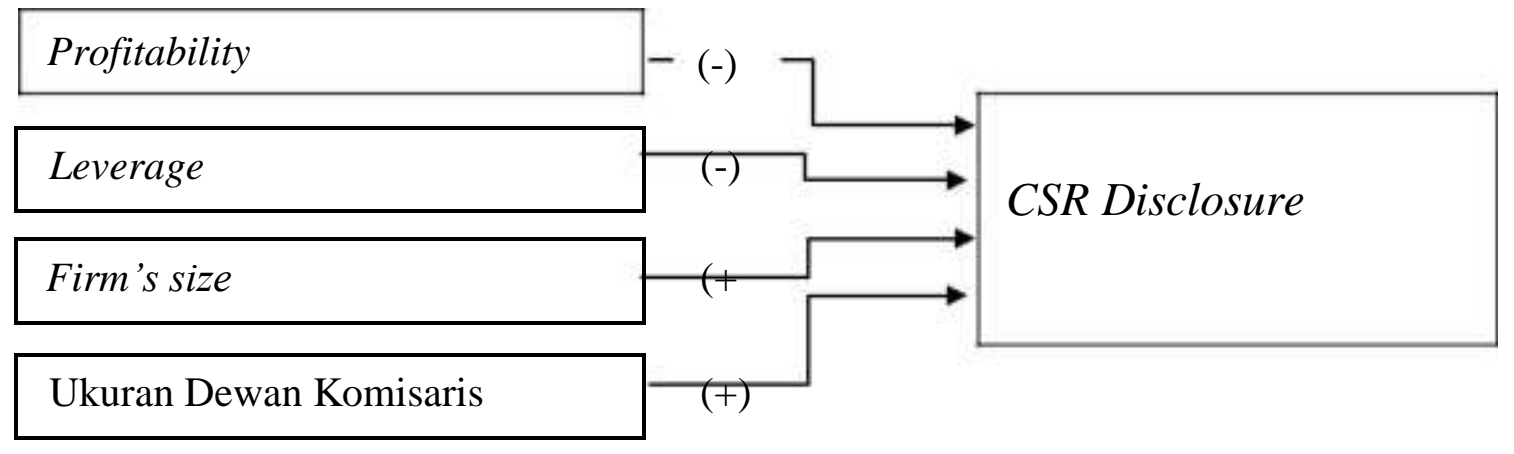




\section{Hipotesis}

Sembiring (2005) menjelaskan bahwa ketika perusahaan memiliki tingkat laba yang tinggi, manajemen menganggap tidak perlu melaporkan hal-hal yang dapat mengganggu informasi tentang sukses keuangan perusahaan. Sebaliknya, pada saat tingkat profitabilitas rendah, mereka berharap para pengguna laporan akan membaca "goodnews" kinerja perusahaan, misalnya dalam lingkup sosial, dan dengan demikian investor akan tetap berinvestasi di perusahaan tersebut. Hal tersebut dapat menunjukkan bahwa profitabilitas mempunyai hubungan yang negatif terhadap tingkat pengungkapan tanggung jawab sosial perusahaan.

Setyorini (2012) juga menjelaskan, perusahaan yang memiliki rencana pemberian bonus, manajer perusahaan akan lebih memilih metode akuntansi yang dapat menggeser laba dari masa depan ke masa kini sehingga dapat menaikkan laba saat ini. Zulaikha (2012) dan Wardhani (2013) menemukan adanya pengaruh positif yang signifikan terhadap profitabilitas. Namun demkian, Kinantika (2013) dan Sembiring (2005) tidak menemukan adanya pengaruh antara profitabilitas dan luas pengungkapan laporan sosial perusahaan. Berdasarkan uraian tersebut maka dapat dirumuskan hipotesis berikut:

\section{H1 : Firm's Profitability berpengaruh negatif terhadap pengungkapan laporan tanggung jawab sosial perusahaan}

Leverage merupakan alat untuk mengukur seberapa besar perusahaan pada kreditur dalam membiayai aset perusahaan. Perusahaan dengan tingkat leverage yang tinggi berarti sangat tergantung pada pinjaman luar untuk membiayai asetnya. Sedangkan perusahaan yang mempunyai tingkat leverage rendah lebih banyak membiayai asetnya dengan modal sendiri. Tingkat leverage perusahaan dapat menggambarkanresiko keuangan perusahaan (Sembiring, 2005). Teori signaling menggambarkan sinyal good news dan bad news dapat juga dilihat dari tingkat leverage. Penelitian yang dilakukan oleh Sembiring (2005); Anggraini (2006); Septiani (2013) tidak menemukan adanya pengaruh leverage terhadap pengungkapan tanggung jawab sosial perusahaan. Namun demikian, Kinantika (2013) menemukan adanya pengaruh negatif pada leverage terhadap pengungkapan tanggung jawab sosial perusahaan. Dari pernyataa

\section{H2 : Leverage perusahaan berpengaruh negatif terhadap pengungkapan tanggung jawab sosial perusahaan.}

Beberapa penelitian empiris telah banyak menyediakan bukti mengenai hubungan antara ukuran perusahaan dengan pengungkapan sosial perusahaan (Belkaoui, 1989; Hackston dan Milne, 1996) dalam Anggraini (2006). Perusahaan besar merupakan emiten yang banyak disoroti, pengungkapan yang lebih besar merupakan pengurangan biaya politis sebagai wujud tanggung jawab sosial perusahaan. Menurut Cowen et al. (1987) dalam Sembiring (2005), secara teoritis perusahaan besar tidak akan lepas dari tekanan, dan perusahaan yang lebih besar dengan aktivitas operasi dan pengaruh yang lebih besar terhadap masyarakat mungkin akan memiliki pemegang saham yang memperhatikan program sosial yang dibuat perusahaan sehingga pengungkapan tanggung jawab sosial perusahaan akan semakin luas. Dari sisi tenaga kerja, dengan semakin banyaknya jumlah tenaga kerja dalamsuatu perusahaan, maka tekanan pada pihak manajemen untuk memperhatikan kepentingan tenaga kerja akan semakin besar. Berdasarkan uraian di atas, maka penelitian ini mengajukan hipotesis sebagai berikut:

\section{H3 : Ukuran perusahaan berpengaruh positif terhadap pengungkapan laporan CSR asuransi.}

Menurut Wardhani (2013), berdasarkan teori agensi, dewan komisaris dianggap sebagai mekanisme pengendalian intern tertinggi, yang bertanggung jawab untuk memonitor tindakan manajemen puncak. Semakin besar jumlah anggota dewan komisaris, maka akan semakin mudah untuk mengendalikan dan monitoring yang dilakukan akan semakin efektif. Dikaitkan dengan pengungkapan tanggung jawab sosial, maka tekanan terhadap manajemen juga akan semakin besar untuk mengungkapkannya hasil menunjukan ukuran dewan komisaris berpengaruh positif terhadap tanggung jawab sosial perusahaan. Penelitian yang dilakukan oleh Sembiring (2005) dan Septiani (2013) menemukan bahwa ukuran dewan komisaris berpengaruh positif terhadap CSR Disclosure. Berdasarkan uraian tersebut, hipotesis keempat yang diajukan dalam penelitian ini adalah: 


\section{H4 : Ukuran Dewan Komisaris berpengaruh positif terhadap pengungkapan laporan tanggung jawab sosial perusahaan.}

\section{METODE PENELITIAN}

Seluruh perusahaan asuransi yang ada di Indonesia dari daftar bursa efek Indonesia merupakan populasi dalam penelitian ini. Sedangkan sampelnya dipilih dengan metode purposive sampling. Kriteria pemilihan sampel adalah sebagai berikut: (i) perusahaan Asuransi yang terdaftar pada Bursa Efek Indonesia (BEI) tahun 2009-2012, (ii) perusahaaan-perusahaan yang menjadi sampel adalah perusahaan asuransi yang mempublikasikan laporan keuangan dan laporan tahunan secara lengkap, dan (iii) memiliki data yang lengkap berkaitan dengan variable-variabel yang digunakan dalam penelitian ini.

Dalam penelitian ini, variabel Dependen ini adalah pengungkapan laporan tanggung jawab social, sedangkan variabel independennya adalah profitabiltas, tingkat levarage, ukuran perusahaan, dan ukuran dewan komisaris.

Tabel 1 Definisi dan Operasionalisasi Variabel

\begin{tabular}{cl}
\hline Variabel Dependen & \\
\hline \multicolumn{1}{c}{ CSRI } & Banyaknya item pengungkapan meliputi lingkungan, energi, \\
& kesehatan dan keselamatan tenaga kerja, lain lain tentang tenaga \\
& kerja, produk, keterlibatan masyarakat dan umum (checklist)*. \\
& Indeks = jumlah skor pengungkapan yang diperoleh/jumlah indikator \\
& yang menjelaskan pengungkapan CSR \\
\hline Variabel Independen & \\
\hline Profitabilitas & laba bersih sesudah pajak dibagi dengan total aktiva. \\
Leverage & total kewajiban dibagi dengan ekuitas pemegang saham. \\
Ukuran Perusahaan & total aktiva \\
juman dewan komisaris & jumlah dewan komisaris perusahaan \\
&
\end{tabular}

* Checklist dilakukan dengan melihat laporan tahunan perusahaan dalam pengungkapan sosialnya dan menandai kategori yang diindikasi mempengaruhi pengungkapan sosial tersebut. Standar indikasi acuan yang digunakan ialah standar kategori yang dibuat oleh Sembiring, tahun 2005 untuk sektor industri perusahaan yang bergerak di bidang keuangan.(lihat lampiran)

Berdasarkan hipotesis yang dirumuskan dalam penelitian ini, metode analisis data yang digunakan adalah metode analisis regresi berganda. Sebelum melakukan analisis regresi berganda dilakukan analisis statistik deskriptif dan uji asumsi klasik untuk memastikan akurasi dan kualitas data. Berikut persamaan regresi penelitian:

$$
\text { CSRI = a + b1 ROA + b2 LEV + b3 SIZE + b4 KOM + e }
$$

Keterangan :

$\begin{array}{ll}\text { CSRl } & =\text { Level pengungkapan CSR } \\ \text { ROA } & =\text { Return on Asset } \\ \text { LEV } & =\text { Hutang jangka panjang } \\ \text { SIZE } & =\text { Ukuran Perusahaan } \\ \text { KOM } & =\text { Ukuran Dewan Komisaris }\end{array}$

\section{HASIL PENELITIAN DAN PEMBAHASAN}

Penelitian ini menggunakan sampel perusahaan asuransi yang selama periode tahun 20092012 mengeluarkan laporan keuangan tahunan berupa annual report yang berisi pengungkapan Corporate Social Responsibility (CSR). Diperoleh bahwa jumlah perusahaan asuransi yang selama tahun 2009 -2012 yang mengeluarkan laporan keuangan tahunan secara kontinyu dan dengan data yang lengkap adalah sebanyak 11 perusahaan. Adapun periode pengamatan selama 4 tahun menjadikan sampel penelitian sebanyak 44 perusahaan. 
Statistik deskriptif memberikan gambaran mengenai variabel-variabel dalam penelitian yang dilihat dari nilai rata- rata (mean), standar deviasi, nilai maksimum, dan nilai minimum. Hasil analisis statistik deskriptif dari masing-masing variabel dalam penelitian menggunakan program SPSS disajikan dalam tabel 2.

Tabel 2 Statistik Deskriptif

\begin{tabular}{|c|c|c|c|c|c|}
\hline & $\mathrm{N}$ & Minimum & Maximum & Mean & Std. Deviation \\
\hline$\overline{\mathrm{ROA}}$ & 44 & 0.0290 & 0.9680 & 0.0885 & 0.1378 \\
\hline LEV & 44 & 0.2720 & 5.6719 & 1.3397 & 1.1222 \\
\hline SIZE & 44 & 25.3361 & 30.3035 & 27.4206 & 1.4655 \\
\hline KOM & 44 & 2.0000 & 6.0000 & 3.4773 & 0.7921 \\
\hline CSRD & 44 & 0.1270 & 0.3175 & 0.2381 & 0.0478 \\
\hline
\end{tabular}

Sumber : Data sekunder yang diolah

Profitabilitas menunjukkan kemampuan perusahaan untuk memperoleh laba. Variabel profitabilitas yang diukur dengan Return on Asset (ROA) menunjukkan rata-rata sebesar 0,0885 atau $8,85 \%$. Hal ini berarti bahwa perusahaan sampel rata-rata mampu mendapatkan laba bersih sebesar $8,85 \%$ dibanding dengan total aset yang dimiliki perusahaan. ROA terendah adalah 0,0290 dan ROA tertinggi adalah 0,9680. Kondisi demikian menunjukkan bahwa seluruh nilai ROA perusahaan sampel bernilai positif yang berarti bahwa perusahaan sampel yaitu perusahaan asuransi selama tahun 2009 - 2012 memiliki kemampuan untuk mendapatkan laba. Nilai deviasi standar variabel ROA adalah sebesar 0,1378 yang menunjukkan bahwa nilai-nilai ROA dari perusahaan sampel sangat bervaiasi yang memungkinkan munculnya data-data ROA yang ekstrim dari nilai ROA perusahaan sampel.

Variabel leverage menunjukkan tingkat hutang yang dimiliki perusahaan. Variabel leverage yang diukur dengan Debt to Equity Ratio (DER) menunjukkan rata-rata sebesar 1,3397. Hal ini berarti bahwa perusahaan sampel rata-rata mampu memiliki hutang sebesar 1,3397 kali dibanding dengan modal sendiri atau ekuitas yang dimiliki perusahaan. Nilai rata-rata DER yang lebih besar dari 1 menunjukkan bahwa perusahaan lebih banyak menggunaan pendanaan dari hutang dibanding modal sendiri. DER terendah adalah 0,2720 dan DER tertinggi adalah 5,6719. Perbedaan nilai DER terendah dengan DER tetinggi cukup besar. Hasil ini juga didukung dengan nilai deviasi standar DER diperoleh sebesar 1,1222 yang relatif lebih tinggi dari nilai rata-rata DER. Hasil ini menunjukkan bahwa nilai DER dari perusahaan sampel memiliki variasi yang cukup tinggi.

Total asset merupakan jumlah keseluruhan asset yang dimiliki oleh perusahaan. Total asset secara umum berasal dari modal sendiri dan juga modal yang berasal dari hutang. Variabel ukuran perusahaan yang diukur dengan menggunakan logaritma natural total asset menunjukkan rata-rata sebesar 27,4206. Ukuran perusahaan (logaritma natural totral asset) terendah adalah sebesar 25,3361 dan ukuran perusahaan publik tertinggi adalah sebesar 30,3035. Nilai deviasi standar In total asset diperoleh sebesar 1,4655. Nilai tersebut jauh lebih kecil dibanding nilai rata-rata variabel penelitian. Hal ini menunjukkan variasi variabel menjadi semakin kecil setelah transfomasi ln dari nilai total asset.

Ukuran dewan komisaris yang merupakan salah satu bentuk pengawasan pada perusahaan dan sampel yang diperoleh sebesar 3,4773 atau sebanyak 3 orang. Hal ini berarti bahwa jumlah anggota dewan komisaris dari perusahaan sampel rata-rata sebanyak 3 orang. Jumlah angota dewan komisaris yang paling sedikit adalah sebanyak 2 orang dan yang paling banyak sebanyak 6 orang. Nilai standar deviasi ukuran dewan komisaris diperoleh sebesar 0,7921. Nilai tersebut relatif kecil dibanding nilai rata-rata ukuran dewan komisaris dari perusahaan sampel. Hal ini menunjukkan bahwa ukuran dewan komisaris masih memiliki variasi yang relatif kecil.

Pengujian model regresi dilakukan dengan menggunakan rumus regresi linier berganda dengan menggunakan bantuan program komputer Statistic Package for Sosial Science (SPSS) versi 16. Selanjutnya akan dibahas mengenai pengujian hipotesis penelitian. Untuk menentukan pengaruh masing-masing variabel independen terhadap variabel dependen di gunakan uji t. Dari 

hasil estimasi regresi pada lampiran diketahui nilai t hitung sebagaimana terlihat di table 3 . Berdasarkan Tabel 3 tersebut diatas dapat diperoleh persamaan regresi untuk mengetahui faktorfaktor dalam memprediksi kelengkapan disclosure sebagai berikut:

$$
\mathrm{CSRD}=-0,364+0,360 \mathrm{ROA}+0,002 \mathrm{LEV}+0,018 \mathrm{SIZE}+0,021 \mathrm{KOM}+\mathrm{e}
$$

Tabel 3 Analisis Regresi

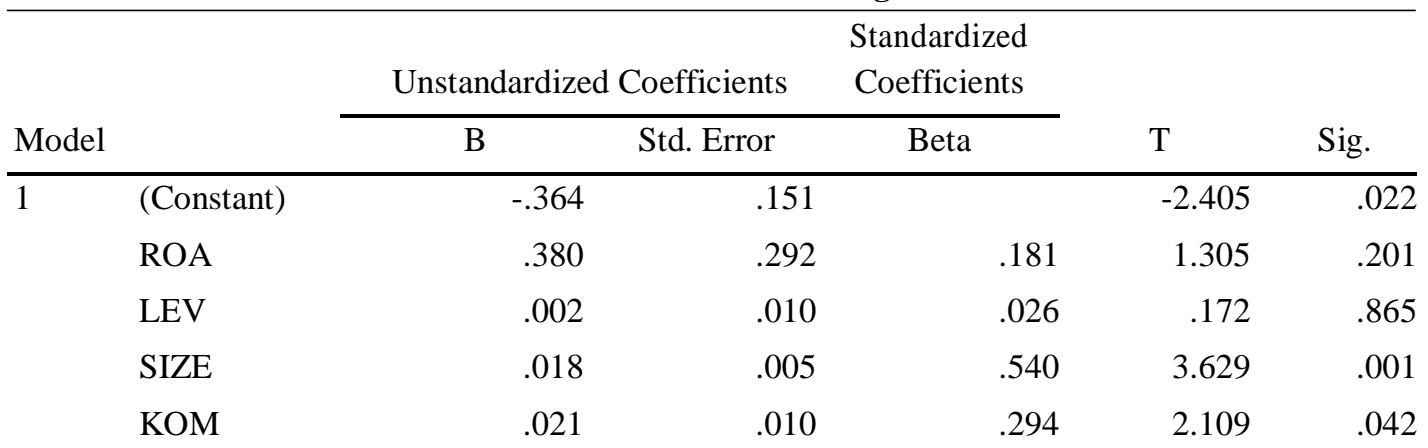

a. Dependent Variable: CSRD

Sumber : Data sekunder yang diolah

\section{Pembahasan}

1. Pengaruh Profitabilitas terhadap Kelengkapan Pengungkapan

Pengujian hipotesis 1 dalam penelitian ini adalah untuk menguji apakah profitabilitas ROA mempengaruhi Pengungkapan CSR. Hasil penelitan menunjukkan nilai t sebesar 1,305 dengan tingkat signifikansi sebesar 0,201 berada lebih besar dari $\alpha=10 \%$, sehingga hasil penelitian ini tidak mendukung hipotesis 1 yang diajukan. Dari sini dapat disimpulkan bahwa profitabilitas (ROA) tidak mempengaruhi CSR.

Rasio profitabilitas diukur dengan menggunakan return on asset (ROA). Hasil pengujian menunjukkan bahwa profitabilitas ROA tidak berpengaruh signifikan terhadap pengungkapan CSRD. Hal ini berarti bahwa perusahaan dengan profitabilitas yang lebih baik tidak berarti akan mengungkapkan CSR yang lebih sempit. Hipotesis awal dari variabel ROA terhadap kelengkapan pengungkapan CSR berkaitan dengan anggapan dasar bahwa dengan informasi laba yang baik maka manajer memiliki satu dasar untuk mengungkapkan kinerja perusahaan secara lebih luas sehingga tidak harus memberikan informasi lain yang lebih lengkap bagi para stakeholder termasuk informasi CSR.

Namun anggapan tersebut tidak bisa diterima, lebih besarnya pengungkapan CSR berkaitan dengan laporan laba yang mengindikasikan bahwa stakeholder lebih membutuhkan kelengkapan laporan perusahaan yang menggambarkan kinerja perusahaan, sehingga pada saat perusahaan mendapatkan laba yang lebih besar maka hal ini belum menjadi legitimasi bagi perusahaan sehingga masih perlu mengungkapkan CSR yang lebih luas. Hal ini berarti bahwa manajer nampaknya memiliki penilaian pada saat perusahaan mendapatkan laba yang tinggi ataupun rendah sekalipun, manajer akan tetap membutuhkan informasi pelengkap yang dapat mendukung good news dari perusahaan akan kemam puan manajemen tersebut sehingga manajer cenderung mengungkapkan CSR secara lebih luas.

Penelitian ini mendukung penelitian yang dilakukan oleh Sembiring (2005), Anggraini (2006) dan Septiani (2013) yang menunjukkan tidak adanya pengaruh yang signifikan antara profitabilitas terhadap CSR Disclosure.

2. Pengaruh Leverage terhadap CSRD

Pengujian hipotesis 2 dalam penelitian ini bertujuan untuk menguji apakah leverage (DER) mempengaruhi Pengungkapan CSR. Hasil penelitan menunjukkan nilai $t$ sebesar 0,172 dengan tingkat signifikansi sebesar 0,865 berada lebih besar dari $\alpha=10 \%$, sehingga hasil penelitian ini tidak mendukung hipotesis 2 yang diajukan. Dapat disimpulkan bahwa leverage DER tidak mempengaruhi Pengungkapan CSR.

Rasio leverage diukur dengan debt to equity ratio (DER). Hasil pengujian menunjukkan bahwa leverage tidak berpengaruh signifikan terhadap pengungkapan CSRD. Hal ini berarti bahwa 
posisi hutang yang lebih besar pada perusahaan sampel tidak secara langsung berkaitan dengan pengungkapan CSR yang dilakukan oleh perusahaan. Bagi perusahaan, posisi DER yang tinggi di satu sisi dianggap sebagai kondisi yang kurang menguntungkan karena perusahaan memiliki tekanan yang besar dalam kewajiban keuangan perusahaan untuk membayar beban kewajiban dan bunganya. Pada kondisi ini manajemen mungkin akan mencoba mengungkapkan laporan lebih sedikit.

Tidak adanya pengaruh yang signifikan yang mengindikasikan bahwa tingkat leverage tidak mempengaruhi CSR Disclosure. Leverage merupakan alat untuk mengukur seberapa besar perusahaan tergantung dengan para kreditur dalam membiayai aktivitas perusahaan. Dengan demikian manajemen perusahaan dengan tingkat leverage yang tinggi cenderung mengurangi pengungkapan tanggung jawab sosial agar tidak menjadi sorotan para debtholdersnya (Sembiring, 2005). Alasan yang melandasi ditolaknya hipotesis ini adalah masih dianggapnya pelaporan CSR perusahaan sebagai voluntary disclosure mengindikasi adanya pengaruh antara variabel tersebut, sedangkan sekarang pelaporan CSR sudah menjadi mandatory disclosure yang diatur oleh UU PT No. 25 dan 40 tahun 2007 sehingga dengan tingkat hutang tinggi maupun rendah, perusahaan akan tetap melaporkan pelaporan CSR untuk para pemangku kepentingan.

Penelitian ini mendukung penelitian yang dilakukan oleh Septiani (2013), Karina (2013) dan Laksmitaningrum (2013) yang tidak menunjukkan adanya pengaruh yang signifikan antara ukuran leverage terhadap CSR Disclosure. Sedangkan penelitian yang dilakukan Wardani (2013) menemukan adanya pengaruh negatif signifikan pada Leverage terhadap CSR Disclosure.

3. Pengaruh Ukuran Perusahaan terhadap CSRD

Pengujian hipotesis 3 dalam penelitian ini adalah untuk menguji apakah ukuran perusahaan mempengaruhi Pengungkapan CSR. Hasil penelitan menunjukkan nilai t sebesar 3,629 dengan tingkat signifikansi sebesar 0,001 berada lebih kecil dari $\alpha=1 \%$, sehingga hasil penelitian ini mendukung hipotesis yang diajukan. Dapat disimpulkan bahwa ukuran perusahaan mempengaruhi Pengungkapan CSR.

Variabel ukuran perusahaan diperoleh memiliki pengaruh positif terhadap CSR. Hasil penelitian ini memberikan dukungan empiris bahwa perusahaan yang besar lebih banyak memiliki informasi daripada perusahaan kecil, sehingga item-item yang harus diungkapkan dalam laporan keuangan termasuk pengungkapan sosial akan menjadi lebih banyak.

Pemerintah dan masyarakat lebih banyak memperhatikan perusahaan besar dibanding perusahaan kecil. Dalam hal ini perusahaan yang besar memandang arti pentingnya pengungkapan sosial dalam menjelaskan kemungkinan-kemungkinan biaya lain-lain yang dikeluarkan. Alasan lain adalah bahwa perusahaan yang lebih besar memiliki masalah keagenan yang lebih besar pula.Perusahaan yang besar cenderung memiliki kepemilikan saham yang lebih banyak sehingga jumlah pemilik saham yang lebih banyak akan memerlukan informasi keuangan yang lebih besar pula. Hasil ini konsisten dengan penelitian sebelumnya yang mendapatkan bahwa perusahaan yang besar akan memiliki peluang yang lebih besar untuk memperhatikan program-program sosial.

Penelitian ini mendukung penelitian yang dilakukan oleh Sembiring (2005), Karina (2013) dan Septiani (2013) yang menunjukkan adanya pengaruh yang signifikan antara ukuran perusahaan terhadap CSR Disclosure.

4. Pengaruh Ukuran Dewan Komisaris terhadap CSRD

Pengujian hipotesis 4 dalam penelitian ini adalah untuk menguji apakah ukuran dewan komisaris mempengaruhi Pengungkapan CSR. Hasil penelitan menunjukkan nilai t sebesar 2,109 dengan tingkat signifikan sebesar 0,042 berada lebih kecil dari $\alpha=5 \%$, sehingga hasil penelitian mendukung hipotesis yang diajukan. Dapat disimpulkan bahwa ukruan dewan komisaris mempengaruhi Pengungkapan CSR.

Hasil penelitian menunjukkan bahwa ukuran dewan memiliki pengaruh yang signifikan terhadap pengungkapan CSR dengan arah positif. Hal ini berarti bahwa perusahaan dengan jumlah anggota dewan yang lebih besar akan mengungkapkan CSR yang lebih luas. Alasan mendasar atas hal ini adalah karena ada pertimbangan bahwa pengungkapan yang lebih luas banyak diperuntukkan untuk kepentingan investor di luar perusahaan. Hal ini dikarenakan pengungkapan laporan CSR yang lebih luas dinilai akan mengurangi masalah keagenan dan asimetri informasi yang terjadi.

Dewan direksi berperan melakukan pengawasan kepada direksi untuk mengurangi masalah keagenan yang ada dalam perusahaan. Dengan demikian jumlah anggota dewan komisaris yang lebih 
banyak akan menjadi pengawas yang lebih besar sehingga pengungkapan informasi CSR yang bersifat sukarela juga menjadi salah satu topik permasalahan yang dihadapai komisaris. Penelitian ini mendukung penelitian yang dilakukan oleh Sembiring (2005), Wardani (2013) dan Septiani (2013) yang menunjukkan adanya pengaruh yang signifikan antara ukuran dewan komisaris terhadap CSR Disclosure.

\section{KESIMPULAN}

Penelitian ini dilakukan untuk menguji faktor-faktor yang dapat mempengaruhi kelengkapan pengungkapan perusahaan yang meliputi profitabilitas, leverage, ukuran perusahaan dan jumlah anggota dewan komisaris. Untuk menentukan perusahaan melakukan pengungkapan CSR.

Dari hasil analisis data, pengujian hipotesis, dan pembahasan, maka dapat ditarik kesimpulan dari penelitian ini sebagai berikut :

1. Secara parsial profitabilitas tidak memiliki pengaruh signifikan terhadap kelengkapan Pengungkapan.

2. Secara parsial leverage tidak memiliki pengaruh signifikan terhadap Kelengkapan Pengungkapan CSR.

3. Secara parsial ukuran perusahaan berpengaruh signifikan terhadap kelengkapan Pengungkapan. Perusahaan yang lebih besar akan mengungkapkan kelengkapan laporan keuangan yang lebih luas.

4. Secara parsial ukuran dewan komisaeis memiliki pengaruh signifikan terhadap Pengungkapan CSR. Perusahaan yang memiliki dewan komisais yang lebih banyak akan mengungkapkan kelengkapan laporan keuangan yang lebih luas.

\section{Keterbatasan Penelitian}

Penelitian ini memiliki keterbatasan-keterbatasan yang sekaligus dapat menjadi referensi bagi penelitian yang akan datang antara lain :

1. Penelitian ini hanya melihat CSR dari penilaian peneliti seorang dalam menentukan Pengungkapan yaitu pelaporan keuangan dari annual report sehingga masih memungkinkan subyektifitas peneliti. Penelitian selanjutnya dapat menggunakan lebih dari 1 panelis untuk pengukuran CSR.

2. Terkadang tidak adanya informasi eksplisit dari pengungkapan, membuat subyektifitas penilaian muncul dalam menilitipengungkapan sukarela.

Demi kesempurnaan penelitian selanjutnya perlu diperhatikan beberapa faktor yang dapat meningkatkan validitas hasil penelitian, yaitu:

1. Penelitian selanjutnya perlu mempertimbangkan penggunaan media pelaporan yang lain yang digunakan untuk menentukanpengungkapan.

2. Pengukuran pengungkapan sukareladapat dilakukan dengan menggunakan lebih dari 1 panelis sehingga dapat memperkecil subyektifitas penilaan.

\section{REFERENSI}

Andreas dan Chrystina Lawer (2011), "Pengaruh Karakteristik Perusahaan Terhadap Pengungkapan Tanggung Jawab Sosial”. Riau: Fakultas Ekonomi Universitas Riau Vol 19, No. 02, 2011.

Anggraini, Fr Reni R. 2006. Pengungkapan Informasi Sosial dan Faktor-Faktor yang Mempengaruhi Pengungkapan Informasi Sosial Dalam Laporan Tahunan (Studi Empiris pada Perusahaan-Perusahaan yang Terdaftar Di Bursa Efek Jakarta). Jurnal Simponsium Nsional Akuntansi IX. Padang, 23-26 Agustus 2006.

Astanti, Dhian Indah, (2007), "Implementasi Good Corporate Governance Bagi Perusahaan Asuransi". Semarang: Program Magister Ilmu Hukum Universitas Diponegoro.

Bestivano, W, (2013), "Pengaruh Ukuran Perusahaan, Umur Perusahaan, Profitabilitas, dan Leverage Terhadap Perataan laba Pada Perusahaan yang Terdaftar di BEI" Padang: Universitas Negeri Padang, pp. 8-7.

Fitriyani, 2012, "Keterkaitan Kinerja Lingkungan, Pengungkapan Corporate Social Responsibility (CSR), dan Kinerja Finansial". Semarang: Fakultas Ekonomika dan Bisnis Universitas Diponegoro, h.30. 
Ghozali, Imam. 2009. Analisis Multivariate dengan Program SPSS. Semarang: Badan Penerbit Universitas Diponegoro.

Hackston, D. and Milne, M, (1996), "Some Determinants Of Social and Environtmental Disclosures in New Zealand Companies". Accounting, Auditing \& Accountability Journal, Vol. 9 No.1, 1996.

Ikatan Akuntan Indonesia (IAI). 2009. ED PSAK No. 01 Paragraf 12 (Revisi 2009). Jakarta: Salemba Empat

Indrawan, Danu Candra, 2011, "Pengaruh Corporate Social Responsibility Terhadap Kinerja Perusahaan". Semarang: Fakultas Ekonomika dan Bisnis Universitas Diponegoro, h.29.

Karina, Lovink Angel Dwi, (2013), "Analisis Faktor - Faktor yang Mempengaruhi Pengungkapan CSR". Semarang: Fakultas Ekonomika dan Bisnis Universitas Diponegoro.

Kinantika, Ervanti Kusuma Ayu, 2013, "Pengaruh Biaya Eksplorasi dan Pengembangan Tangguhan, Leverage, dan Profitabilitas Terhadap Luas Pengungkapan Corporate Social Responsibility". Semarang: Fakultas Ekonomika dan Bisnis Universitas Diponegoro.

Laksmitaningrum, Chintya Fadila, 2013, Analisis Pengaruh karakteristik Perusahaan, Ukuran Dewan Komisaris, dan Struktur Kepemilikan Terhadap pengungkapan CSR. Semarang: Fakultas Ekonomika dan Bisnis Universitas Diponegoro.

Mahardian, Pandu (2008) Analisis Rasio CAR, BOPO, NPL, NIM, dan LDR Terhadap Kinerja Keuangan Perbankan. Semarang: Magister Manajemen Program Studi Pascasarjana Universitas Diponegoro.

McKinnon, H dan Jamal, M, (2005), The Power of Giving. Jakarta: UFUK Press, Desember 2011.

Pambudi, T. 2006. Perjalanan Si Konsep Seksi. Majalah SWA. Vol. 26 (XXI/19). 11 Januari. Hal:44-45.

Republik Indonesia. 2007. Undang undang RI No. 40 Tahun 2007 tentang Perseroan Terbatas. Lembaran Negara RI tahun 2007, no.74. Jakarta : Sekertariat Kabinet RI.

Sekaran, Uma (2006) Research Methods For Business. Jakarta: Salemba Empat.

Sembiring, Eddy R. 2005. Karakteristik Perusahaan dan Pengungkapan Tanggung Jawab Sosial: Study Empiris Pada Perusahaan yang Tercatat di Bursa Efek Jakarta. Simposium Nasional Akuntansi VIII. Surakarta.

Septiani, Mita (2013), "Pengaruh Karakteristik Perusahaan Terhadap Corporate Social Responsibility Disclosure dan Implikasinya Terhadap Earning Per Share". Semarang : Fakultas Ekonomika dan Bisnis Universitas Diponegoro.

Veronica, Theodora Martina (2009), "Pengaruh Karakteristik Perusahaan Terhadap Pengungkapan Tanggung Jawab Sosial Pada Perusahaan Sektor Pertambangan yang Terdaftar di Bursa Efek Indonesia", Jakarta: Fakultas Ekonomi Universitas Gunadarma, h.2.

Wardani, Nurul Kusuma (2013), "Pengaruh Karakteristik Perusahaan Terhadap Pengungkapan Corporate Social Responsibility (CSR)". Semarang: Fakultas Ekonomika dan Bisnis Universitas Diponegoro.

Zulaikha, Dewi Yulfaida (2012), "Pengaruh Size, Profitabilitas, Profile, Leverage, dan Ukuran Dewan Komisaris Terhadap Pengungkapan Tanggung Jawab Sosial Pada Perusahaan Manufaktur di Bursa Efek Indonesia". Diponegoro Journal of Accounting. http://ejournalsl.undip.ac.id/index.php/accounting . 


\section{Lampiran II \\ Indikator CSRD Perusahaan Asuransi}

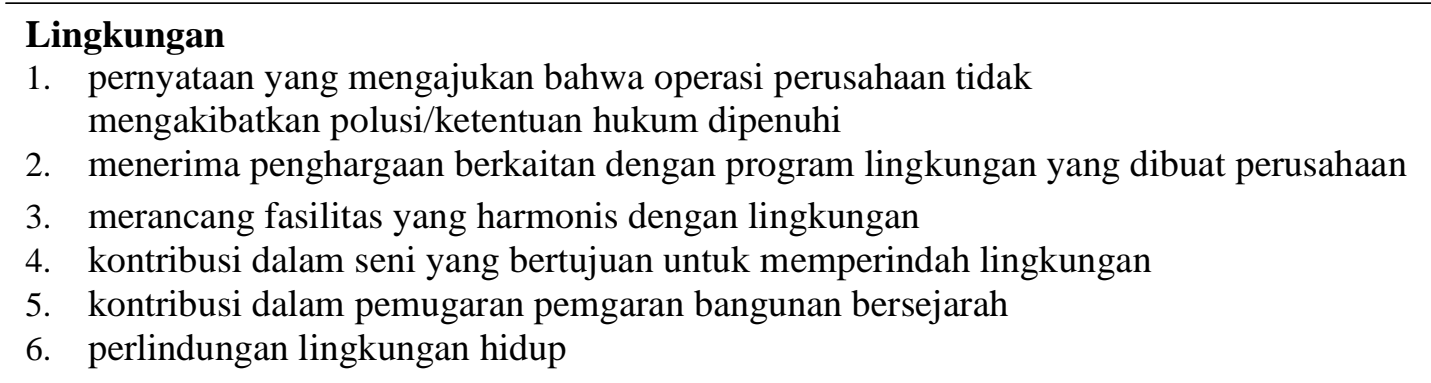

\section{Energi}

1. menggunakan energi secara lebih efisien dlm keg operasi

2. membahas upaya perusahaan dalam mengurangi konsumsi energi

3. mengungkapkan kebijakan energi perusahaan

\section{Kesehatan Dan Keselamatan Tenaga kerja}

1. Mengurangi polusi, iritasi, atau resiko dalam lingkungan kerja

2. Mempromosikan keselamatan tenaga kerja dan kesehatan fisik atau mental

3. Mengungkapkan statistik kecelakaan kerja

4. Mentaati peraturan standard kesehatan dan keselamatan kerja

5. Menerima penghargaan berkaitan dengan keselamatan kerja

6. Menetapkan suatu komite keselamatan kerja

7. Melaksanakan riset untuk meningkatkan keselamatan kerja

8. Mengungkapkan pelayanan kesehatan tenaga kerja

\section{Lain-lain tentang Tenaga kerja}

1. Perekrutan atau memanfaatkan tenaga kerja wanita/orang cacat

2. Mengungkapkan persentase/jumlah tenaga kerja wanita/orang cacat dalam tingkat managerial

3. Mengungkapkan tujuan penggunaan tenaga kerja wanita/orang cacat dalam pekerjaan

4. Program untuk kemajuan tenaga kerja wanita/orang cacat

5. Pelatihan tenaga kerja melalui program tertentu di tempat kerja

6. Memberi bantuan keuangan pada tenaga kerja dalam bidang pendidikan

7. Mendirikan suatu pusat pelatihan tenaga kerja.

8. Mengungkapkan bantuan atau bimbingan untuk tenaga kerja yang dalam proses mengundurkan diri atau yang telah membuat kesalahan

9. Mengungkapkan perencanaan kepemilikan rumah karyawan

10. Mengungkapkan fasilitas untuk aktivitas rekreasi

11. Pengungkapkan persentase gaji untuk pensiun

12. Mengungkapkan kebijakan penggajian dalam perusahaan

13. Mengungkapkan jumlah tenaga kerja dalam perusahaan

14. Mengungkapkan tingkatan managerial yang ada

15. Mengungkapkan disposisi staff - di mana staff ditempatkan

16. Mengungkapkan jumlah staff, masa kerja dan kelompok usia mereka

17. Mengungkapkan statistik tenaga kerja, mis. penjualan per tenaga kerja

18. Mengungkapkan kualifikasi tenaga kerja yang direkrut.

19. Mengungkapkan rencana kepemilikan saham oleh tenaga kerja

20. Mengungkapkan rencana pembagian keuntungan lain.

21. Mengungkapkan informasi hubungan manajemen dengan tenaga kerja dalam meningkatkan kepuasan dan motivasi kerja

22. Mengungkapkan informasi stabilitas pekerjaan tenaga kerja dan masa depan perusahaan

23. Membuat laporan tenaga kerja yang terpisah depan perusahaan;

24. Melaporkan hubungan perusahaan dengan serikat buruh

25. Melaporkan gangguan dan aksi tenaga kerja

26. Mengungkapkan informasi bagaimana aksi tenaga kerja dinegosiasikan.

27. Peningkatan kondisi kerja secara umum;

28. Informasi re-organisasi perusahaan yang mempengaruhi tenaga kerja;

29. Informasi dan statistik perputaran tenaga kerja

\section{Produk}

1. Pengungkapan informasi pengembangan produk perusahaan, termasuk pengemasanya

2. Gambaran pengeluaran riset dan pengembangan produk; 
3. Pengungkapan informasi proyek riset perusahaan untuk memperbaiki produk

4. Membuat produk lebih aman untuk konsumen;

5. Pengungkapan informasi mutu produk yang dicerminkan dalam penerimaan penghargaan

6. Informasi yang dapat diverifikasi bahwa mutu produk telah meningkat (Misalnya ISO 9000).

\section{Keterlibatan Masyarakat}

1. Sumbangan tunai, produk, pelayanan untuk mendukung aktivitas masyarakat, pendidikan, dan seni

2. Tenaga kerja paruh waktu (part-time employment) dari mahasiswa/pelajar

3. Sebagai sponsor untuk proyek kesehatan masyarakat;

4. Membantu riset medis;

5. Sebagai sponsor untuk konferensi pendidikan, seminar atau pameran seni

6. Membiayai program beasiswa

7. Membuka fasilitas perusahaan untuk masyarakat;

8. Mensponsori kampanye nasional;

9. Mendukung pengembangan industri local

\section{Umum}

1. Pengungkapan tujuan/kebijakan perusahaan secara umum berkaitan dengan tanggung jawab sosial perusahaan kepada masyarakat

2. Informasi berhubungan dengan tanggung jawab sosial perusahaan selain yang disebutkan diatas 